\title{
Pregnenolone sulfate regulates prolactin production in the rat pituitary
}

\author{
Eun-Jin Kang', So-Hye Hong', Jae-Eon Lee', Seung Chul Kim², Hoe-Saeng Yang, \\ Pyong in $\mathrm{Yi}^{4}$, Sang-Myeong Lee ${ }^{5}$ and Beum-Soo An ${ }^{1}$
}

1Department of Biomaterials Science, College of Natural Resources and Life Science/Life and Industry Convergence Research Institute, Pusan National University, Milyang, Republic of Korea 2Department of Obstetrics and Gynecology, Biomedical Research Institute, Pusan National University School of Medicine, Milyang, Republic of Korea

3Department of Obstetrics and Gynecology, Medical College, Dongguk University, Seoul, Republic of Korea ${ }^{4}$ Department of Bioenvironmental Energy, College of Natural Resources and Life Science, Pusan National University, Milyang, Republic of Korea

${ }^{5}$ College of Environmental and Bioresource Sciences, Chonbuk National University, Jeonju, Republic of Korea

\author{
Correspondence \\ should be addressed \\ to B-S An \\ Email \\ anbs@pusan.ac.kr
}

\begin{abstract}
Pregnenolone sulfate (PS) is a neuroactive steroid hormone produced in the brain. In this study, the effects of PS on synthesis and secretion of rat pituitary prolactin (PRL) were examined. To accomplish this, GH3 rat pituitary adenoma cells were treated with PS, which showed significantly increased mRNA and protein levels of PRL compared with the control. The mechanism of action responsible for the effects of PS on PRL synthesis and secretion was investigated by pretreating cells with inhibitors of traditional PRLor the PS-related signaling pathway. PS-stimulated PRL transcription was significantly reduced by inhibitors of PKA, PKC and MAPK, but unchanged by GABAAR and NMDAR inhibitors. Western blotting analysis revealed that the total ERK1/2 level was upregulated in a time-dependent manner following PS treatment. An approximate 10\% increase in $\mathrm{GH} 3$ cell proliferation was also observed in response to PS relative to the control. In the animal study, levels of PRL in the pituitary and in serum were elevated by PS. PS-stimulated PRL synthesis was also found to be associated with decreased expression of PRL target genes such as GNRH1, FSHB and LHB. These findings show that PS upregulates PRL synthesis and secretion in vivo and in vitro via MAPK signaling, suggesting that it has the potential for use as a therapeutic hormone to treat PRLrelated disorders such as hypoprolactinemia and low milk supply.
\end{abstract}

\author{
Key Words \\ - pregnenolone sulfate \\ - neurosteroid \\ - pituitary prolactin
}

Journal of Endocrinology (2016) 230, 339-346

\section{Introduction}

Prolactin (PRL) is a polypeptide hormone synthesized and secreted from specialized cells of the anterior pituitary gland, which is known for its multiple effects on the female mammary gland, including regulation of growth and development of the gland (mammogenesis), synthesis of milk (lactogenesis) and maintenance of milk secretion (galactopoiesis) (Freeman et al. 2000). In addition, the range of PRL functions has greatly increased in females and males. An early review revealed that PRL had 85 functions (Cowie 1973), which has subsequently

Published by Bioscientifica Ltd. 
been updated to over 300, including immune functions, reproduction, osmoregulation and behavior (Bole-Feysot et al. 1998).

PRL-inhibiting factors (PIFs) and PRL-releasing factors (PRFs) supplied by neurosecretory cells control synthesis and secretion of PRL from the pituitary (Arey et al. 1989, Lamberts \& Macleod 1990). The PIF includes dopamine (DA), somatostatin and gamma-aminobutyric acid (GABA), whereas PRF includes thyrotropin-releasing hormone (TRH), neurotensin and oxytocin. Internal milieu such as suckling, stress and increased levels of ovarian steroids modulate PRF and PIF activities, which transduce PRL-regulating signals (Meites et al. 1963, Neill 1970, Terkel et al. 1972).

DA is the predominant hypothalamic factor involved in regulation of PRL synthesis and secretion. In addition, factors influencing the dopaminergic tone in lactotrophs have been investigated to illuminate the complex connection between PRL and DA. DA directly influences lactotrophs by binding to the D2 receptor (D2R) subclass expressed on their cell membranes (Lefkowitz \& Labrie 1978). Other pituitaryderived factors also regulate PRL secretion, including transforming growth factor alpha (TGF- $\alpha$ ), transforming growth factor beta (TGF- $\beta$ ), interleukins and galanin (Sarkar et al. 1998). In addition, the secretion and synthesis of PRL are modulated by calcium $\left(\mathrm{Ca}^{2+}\right)$ concentration. PRL secretion is sensitive to changes in extracellular $\mathrm{Ca}^{2+}$ concentration in normal rat pituitary cells in vitro. TRH stimulates PRL release via elevated intracellular free $\mathrm{Ca}^{2+}$ (Gershengorn 1986). Chelation of extracellular $\mathrm{Ca}^{2+}$ has been shown to reduce PRL secretion and synthesis in the GH3 pituitary cells. TRH-stimulated PRL secretion is also suppressed by reduction of $\mathrm{Ca}^{2+}$ and verapamil $\left(\mathrm{Ca}^{2+}\right.$ channel blocker) (Gershengorn \& Thaw 1985).

Transcription of PRL likely involves activation of protein kinases, which leads to phosphorylation of specific regulators such as PIF and PRF. Activation of cAMP-dependent protein kinase (PKA), protein kinase $\mathrm{C}$ (PKC), $\mathrm{Ca}^{2+} /$ calmodulin-dependent protein kinase type II, or the mitogen-activated protein kinase (MAPK) cascade has been shown to be sufficient to stimulate transcription of the PRL gene. The PRL promoter contains multiple binding sites for tissue-specific transcription factor including pituitary-specific positive transcription factor 1(PIT-1), and PIT-1 binding sites may contribute to hormonally regulation and basal transcription of PRL. The finding that cAMP or phorbol ester treatment of
GH3 cells stimulates phosphorylation of PIT-1 is consistent with a role of PIT-1 in regulation of PRL transcription (Kapiloff et al. 1991).

Pregnenolone sulfate (PS) is an endogenous neuroactive steroid metabolized from pregnenolone (P5), which is a precursor of endogenous steroid hormones such as progesterone (P4) and estrogen $\left(\mathrm{E}_{2}\right)$. Neuroactive steroids synthesized directly in the brain are independent from peripheral sources and rapidly alter neuronal excitability by binding to their receptors (Baulieu 1998). PS is endogenously present in the brain and synthesized by glial cells, which has been shown to modulate neurotransmission in a variety of systems via both presynaptic and postsynaptic mechanisms (Bowlby 1993). PS is also known to have cognitive and memoryenhancing, antidepressant, anxiogenic and proconvulsant effects (Reddy 2010).

Although PS is defined as a neurosteroid hormone, its mechanisms and functions have not been well established. Neuroactive steroids including PS could affect the pituitary cells (Le Foll 1997). Therefore, this study examined the effects of PS on synthesis and secretion of PRL and also the PRL target genes in the rat pituitary.

\section{Materials and methods}

\section{Cell culture and treatments}

GH3 rat pituitary epithelial-like tumor cells were cultured in DMEM (Gibco) supplemented with 10\% fetal bovine serum (FBS; Welgene, Seoul, Korea), 100 U/mL penicillin, and $100 \mu \mathrm{g} / \mathrm{mL}$ streptomycin (Welgene) at $37^{\circ} \mathrm{C}$ in a humidified atmosphere of $5 \% \mathrm{CO}_{2}$ and 95\% air. Cells were seeded in DMEM culture medium. After $24 \mathrm{~h}$ the medium was replaced by phenol red-free DMEM (Sigma-Aldrich) supplemented with 10\% charcoal/dextran-treated FBS (Hyclone, Logan, UT, USA), $100 \mathrm{U} / \mathrm{mL}$ penicillin and $100 \mu \mathrm{g} / \mathrm{mL}$ streptomycin for $24 \mathrm{~h}$ before treatment. All the chemicals for treatment were dissolved in ethanol, diluted with experimental medium, and added to the cell culture medium. The tumor cells were treated with $\mathrm{E}_{2}(100 \mathrm{nM}), \mathrm{P} 4(10 \mu \mathrm{M})$, P5 $(10 \mu \mathrm{M})$, PS $(100 \mu \mathrm{M})$ or ethanol (EtOH) to obtain the vehicle control. The cells were also pretreated with muscimol (Mus; $10 \mu \mathrm{M})$, 3-[(R)-2-carboxypiperazin4-yl]-prop-2-enyl-1-phosphonic acid (CPP; $10 \mu \mathrm{M})$, H89 $(10 \mu \mathrm{M})$, staurosporine (Sta; $1 \mu \mathrm{M})$ or PD98059 (PD; $10 \mu \mathrm{M}) 1 \mathrm{~h}$ before PS treatment to block PRL or PS signaling.

Published by Bioscientifica Ltd. 


\section{Experimental animals and treatments}

Immature female Sprague-Dawley $(n=30)$ rats were acquired from Samtako (Osan, Republic of Korea). The rats were housed at the Pusan National University Laboratory Animal Resources Center, which is accredited by the Korea FDA, according to the National Institutes of Health guidelines. The rats were housed in cages under a $12 \mathrm{~h}$ light: $12 \mathrm{~h}$ darkness cycle and a constant temperature of $23 \pm 1^{\circ} \mathrm{C}$. The Ethics Committee of Pusan National University (Busan, Republic of Korea) approved all experimental animal procedures (approval number; PNU-2014-0665). Rats were treated daily with PS (10 mg/kg/day), $\mathrm{E}_{2} \quad(40 \mu \mathrm{g} / \mathrm{kg} /$ day $), \quad \mathrm{P} 4 \quad$ (1 mg/kg/day), P5 $(10 \mathrm{mg} / \mathrm{kg} / \mathrm{day})$ or corn oil (vehicle control) via subcutaneous injection (SC) from postnatal days (PNDs) 17 to 19. Dosage was adjusted according to changes in body weight (BW); BW, clinical signs and abnormal behaviors were recorded daily throughout the experimental period. On PND 20, all animals were killed using $\mathrm{CO}_{2}$ gas, after which tissue and serum samples were collected.

\section{Quantitative real-time PCR}

Total RNA was extracted using TRIzol reagent (Invitrogen) according to the manufacturer's protocol. RNA was measured using a spectrophotometer. Firststrand complementary DNA (cDNA) was prepared from total RNA $(3 \mu \mathrm{g})$ by reverse transcription (RT) using M-MLV reverse transcriptase (Invitrogen) and random primers (9-mers; Takara Bio). Quantitative real-time PCR (Q-PCR) was performed using cDNA template $(2 \mu \mathrm{L})$ and $2 \times$ Power SYBR Green $(6 \mu \mathrm{L}$; TOYOBO Co Ltd, Katata, Ohtsu, Japan) containing specific primers. Primer sequences for PRL, D2R, PIT-1, V-Ets Avian Erythroblastosis Virus $\mathrm{E}_{2} 6$ Oncogene Homolog 1 (ETS-1), gonadotropin-releasing hormone (GNRH1), gonadotropin- $\alpha$, follicle-stimulating hormone beta (FSHB), and luteinizing hormone beta (LHB) are shown in Table 1. Real-time PCR was conducted by subjecting the samples to 40 cycles of denaturation at $95^{\circ} \mathrm{C}$ for $15 \mathrm{~s}$, followed by annealing and extension at $70^{\circ} \mathrm{C}$ for $60 \mathrm{~s}$. Fluorescence intensity was measured at the end of the extension phase of each cycle. The threshold value for fluorescence intensity of all samples was set manually. The reaction cycle at which the PCR products exceeded this fluorescence intensity threshold during the exponential phase of PCR amplification was considered to be the threshold cycle (CT). Expression of the target gene was quantified relative to that of $\beta$-actin, a ubiquitous housekeeping gene, based on the comparison of CTs at constant fluorescence.

\section{Western blotting analysis}

Protein samples of GH3 cells were extracted with cell lysis buffer $(20 \mathrm{mM}$ Tris, $100 \mathrm{mM} \mathrm{NaCl}, 0.5 \% \mathrm{NP}-40,0.5 \mathrm{mM}$ EDTA, $0.5 \%$ protease inhibitor cocktail). A total $30 \mu \mathrm{g}$ of protein $(15 \mu \mathrm{L}$ of protein in serum, $n=3)$ were separated by $10-12 \%$ sodium dodecyl sulfate polyacrylamide gel electrophoresis (SDS-PAGE) and then transferred to nitrocellulose membranes (Daeillab Service Co, Ltd, Seoul, Korea). Membranes were subsequently blocked for $1 \mathrm{~h}$ with $5 \%$ skim milk (Difco, Spark, MD, USA) in Tris-buffered saline (TBS) with $0.05 \%$ Tween 20 (TBS-T). The blocked membranes were incubated with antibodies specific for PRL, extracellular signal-regulated kinases

Table 1 Primer sequences for Q-PCR analyses.

\begin{tabular}{|c|c|c|c|}
\hline Gene name & Primer & Sequence $\left(5^{\prime}-3^{\prime}\right)$ & Fragment $(b p)$ \\
\hline \multirow[t]{2}{*}{ PRL } & Forward & AGTCTGTTCTGGTGGCGACT & 171 \\
\hline & Reverse & GAAGTGGGGCAGTCATTGAT & \\
\hline \multirow[t]{2}{*}{$\mathrm{D} 2 \mathrm{R}$} & Forward & CATTGTCTGGGTCCTGTCCT & 154 \\
\hline & Reverse & GACCAGCAGAGTGACGATGA & \\
\hline \multirow[t]{2}{*}{ PIT-1 } & Forward & TCAGTATCGCCGCTAAGGAT & 151 \\
\hline & Reverse & CGTTTTTCTCTCTGCCTTCG & \\
\hline \multirow[t]{2}{*}{ ETS-1 } & Forward & TTGCCATCAAGCAAGAAGTG & 205 \\
\hline & Reverse & ТТССТСТТTССССАТСТССТ & \\
\hline \multirow[t]{2}{*}{ GNRH1 } & Forward & AGCACTGGTCCTATGGGTTG & 248 \\
\hline & Reverse & GTCACACTCGGATGTTGTGG & \\
\hline \multirow[t]{2}{*}{ Gonadotropin- $\alpha$} & Forward & CAGAAGATATGCGGCTGTCA & 184 \\
\hline & Reverse & GTATGCCCTGGAGAAGCAAC & \\
\hline \multirow[t]{2}{*}{ FSHB } & Forward & AAGTCGATCCAGCTTTGCAT & 248 \\
\hline & Reverse & CAGCCAGGCAATCTTATGGT & \\
\hline \multirow[t]{2}{*}{ LHB } & Forward & ATCACCTTCACCACCAGCAT & 229 \\
\hline & Reverse & GACCCCCACAGTCAGAGCTA & \\
\hline
\end{tabular}

http://joe.endocrinology-journals.org DOI: $10.1530 / \mathrm{JOE}-16-0088$
() 2016 Society for Endocrinology Printed in Great Britain
Published by Bioscientifica Ltd 
1/2 (ERK1/2), phosphorylated ERK1/2 (p-ERK1/2), p38-MAPK (p38), and phosphorylated p38 (p-p38) overnight at $4^{\circ} \mathrm{C}$ as well as horse radish peroxidase (HRP)-conjugated anti-rabbit and anti-goat secondary antibodies (diluted 1:2000) in 5\% skim milk with PBS-T for $1 \mathrm{~h}$. Luminol reagent (Bio-Rad) was used to visualize antibody binding. Each blot was scanned using Gel Doc 1000, version 1.5 (Bio-Rad), and band intensities were normalized to $\beta$-actin levels or total protein by from Coomassie Brilliant Blue (Biosesang, Seongnam, Korea) staining.

\section{MTT assay}

GH3 cells $\left(3 \times 10^{4}\right.$ cells/well $)$ were seeded on 96-well plates in $200 \mu \mathrm{L}$ DMEM containing $10 \%$ FBS, $100 \mathrm{U} / \mathrm{mL}$ penicillin, and $100 \mu \mathrm{g} / \mathrm{mL}$ streptomycin. Cells were then allowed to attach to the bottom during $24 \mathrm{~h}$ of incubation, after which the seeding medium was removed and replaced with experimental medium (phenol red-free DMEM supplemented with $10 \%$ charcoal/dextran-treated FBS, $100 \mathrm{U} / \mathrm{mL}$ penicillin and $100 \mu \mathrm{g} / \mathrm{mL}$ streptomycin) for $24 \mathrm{~h}$ before treatment. Cells were treated with $\mathrm{E}_{2}(100 \mathrm{nM})$, P4 $(10 \mu \mathrm{M})$, PS $(100 \mu \mathrm{M})$ or EtOH (vehicle control) for $24 \mathrm{~h}$, after which $50 \mu \mathrm{L}$ 3-(4, 5-dimethylthiazol-2-yl)-2, 5 diphenyl tetrazolium bromide (MTT) solution $(2 \mathrm{mg} / \mathrm{mL})$ was added to $200 \mu \mathrm{L}$ medium without phenol red, and the plates were incubated for $4 \mathrm{~h}$ at $37^{\circ} \mathrm{C}$. DMSO was added to all wells and mixed thoroughly to dissolve the dark blue crystals. After a few minutes at room temperature to ensure that all crystals were dissolved, the absorbance in the wells was measured at $570 \mathrm{~nm}$ with a reference wavelength of $650 \mathrm{~nm}$.

\section{Cell proliferation assay}

5-bromo-2'-deoxyuridine (BrdU) assays were conducted using Cell Proliferation ELISA, BrdU kit (Roche) according to the manufacturer's recommendations. GH3 cells were cultured in the same condition with MTT assay. Cells were treated with $\mathrm{E}_{2}(100 \mathrm{nM})$, PS $(100 \mu \mathrm{M})$ or EtOH (vehicle control) for $24 \mathrm{~h}$, after which $10 \mu \mathrm{L}$ BrdU solution $(100 \mu \mathrm{M})$ were added to each well in $100 \mu \mathrm{L}$ phenol redfree medium, and the plates were incubated for $8 \mathrm{~h}$ at $37^{\circ} \mathrm{C}$. Then the cells were fixed using $200 \mu \mathrm{L}$ FixDenat (Roche) for each well for $30 \mathrm{~min}$, and incubated with BrdU antibody for $90 \mathrm{~min}$ at room temperature. After washing, the cells were incubated with $100 \mu \mathrm{L}$ substrate for $30 \mathrm{~min}$ and then $25 \mu \mathrm{L} 1 \mathrm{M} \mathrm{H}_{2} \mathrm{SO}_{4}$ were added. Absorbance was measured at $450 \mathrm{~nm}$.

\section{Statistical analyses}

The results are presented as mean \pm standard deviation (s.D.). Data were analyzed using one-way analysis of variance (ANOVA) (SPSS for Windows, Release 10.10, Standard Version, Chicago, IL, USA). $P$ values $<0.05$ were considered statistically significant.

\section{Results}

\section{Regulation of PRL expression by PS in GH3 cells}

To investigate the effects of PS on pituitary PRL regulation, GH3 cells were treated with PS or its metabolites, including $\mathrm{E}_{2}, \mathrm{P} 4$ and P5 for $24 \mathrm{~h}$. The mRNA and protein levels of PRL were upregulated in response to PS by approximately two- to three-folds, whereas P4 and P5 reduced the PRL mRNA and protein

A

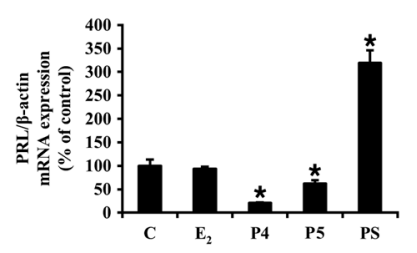

C

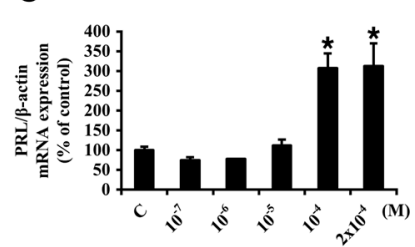

E

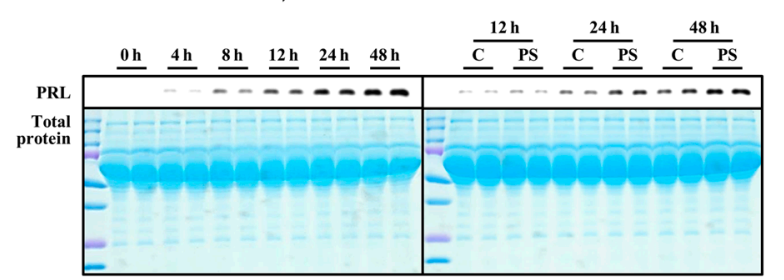

Figure 1

Regulation of PRL expression by PS in GH3 cells. Transcriptional (A) and translational (B) levels of PRL were evaluated after treatment of $\mathrm{GH} 3$ cells with $E_{2}, P 4, P 5$ and PS. The mRNA expression of PRL after PS treatment was tested in a dose-dependent (C) and time-dependent (D) manner. (E) Protein production of PRL in growth medium secreted from GH3 cells was analyzed. The mRNA and protein levels were analyzed by Q-PCR and Western blotting assay. Data are expressed as the mean \pm S.D. of triplicate experiments. The expression level of PRL was normalized to that of an internal control, $\beta$-actin. Protein in growth medium was normalized to total protein stained with Coomassie Brilliant Blue. ${ }^{*} P<0.05$ relative to the control group. A full colour version of this figure is available at http://dx.doi.org/JOE-16-0008.

Published by Bioscientifica Ltd 
levels (Fig. 1A and B). These results suggest that PS upregulates PRL synthesis, which is different from its precursor (P5) and metabolites ( $\mathrm{E}_{2}$ and $\left.\mathrm{P} 4\right)$. Treatment with increasing concentrations $\left(10^{-7}, 10^{-6}, 10^{-5}, 10^{-4}\right.$ and $2 \times 10^{-4} \mathrm{M}$ ) of PS for $24 \mathrm{~h}$ resulted in significantly elevated PRL mRNA levels at concentrations of $10^{-4}$ and $2 \times 10^{-4} \mathrm{M}$ in a dose-dependent manner (Fig. 1C). In Fig. 1D, the basal expression of PRL mRNA was gradually decreased according to the duration of culture, which may be due to autocrine regulation of PRL itself. The mRNA expression was upregulated from 8 to $48 \mathrm{~h}$ when the cells were treated with PS, with the maximum effect occurring at $24 \mathrm{~h}$ compared with control (Fig. 1D). To confirm the regulation of PRL by PS, we further examined the amount of PRL in a medium of GH3 cells after PS treatment (Fig. 1E). The amount of PRL in the cell culture media was enhanced as the cell culture time goes as we expected. Similar to mRNA levels, the amount of PRL in the media was increased by PS compared with control.

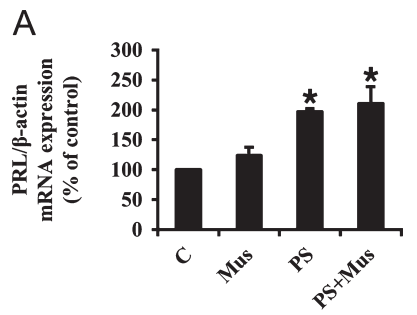

\section{B}
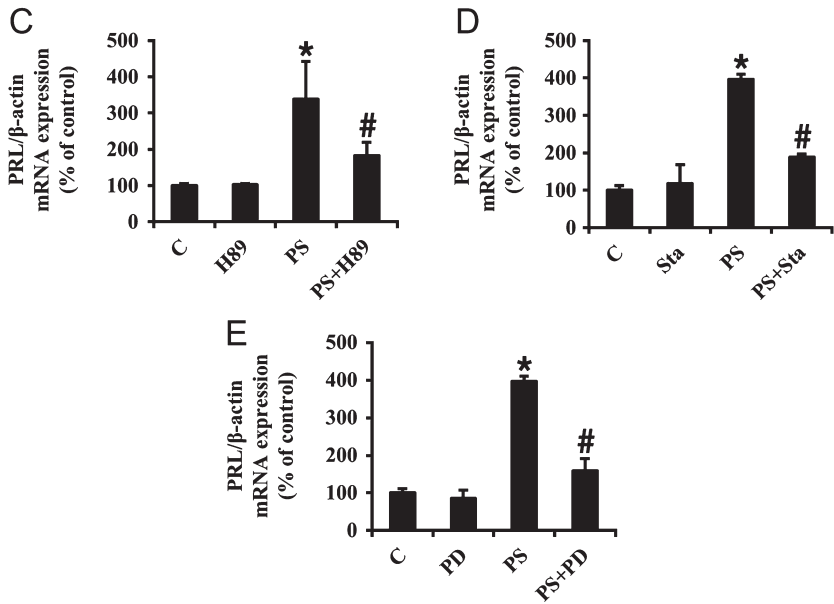

Figure 2

Effects of signaling inhibitors on mRNA levels of PRL upregulated by PS GH3 cells were treated with PS alone or with Mus (A), CPP (B), H89 (C), Sta (D) and PD (E). After treatment of GH3 cells with PS alone or with signaling inhibitors, mRNA levels of PRL were examined by Q-PCR. Data represent the mean \pm S.D. of triplicate experiments. The mRNA expression level was normalized to that of an internal control gene, $\beta$-actin. $* P<0.05$ compared with the control group; $\# P<0.05$ based on the comparison of combined treatment and treatment with PS alone.

\section{Mechanisms of PRL regulation by PS in GH3 cells}

GH3 cells were pretreated with the type-A GABA receptor $\left(\mathrm{GABA}_{\mathrm{A}} \mathrm{R}\right)$ activator, Mus, or the $N$-methyl-D-aspartate receptor (NMDAR) inhibitor, CPP, for $1 \mathrm{~h}$ before PS administration to examine how PS regulates PRL levels. Neither Mus nor CPP significantly altered PRL mRNA levels (Fig. 2A and B). These results suggest that PRL transcription stimulated by PS in GH3 cells is not mediated by $\mathrm{GABA}_{\mathrm{A}} \mathrm{R}$ - or NMDAR-related signaling pathways. To further explore PS signaling, we pretreated GH3 cells with PKA inhibitor (H89), PKC inhibitor (Sta) or MAPK inhibitor (PD) for $1 \mathrm{~h}$ before PS. Enhanced transcription of PRL in response to PS was significantly inhibited by H89, Sta and PD compared with PS alone (Fig. 2C, D and E). Total ERK1/2 or phosphorylated forms of ERK1/2 and p38 were examined by Western blotting. The total ERK1/2 level was elevated in a time-dependent manner, peaking at $10-30 \mathrm{~min}$ after PS treatment (Fig. 3A). However, no significant change in p-ERK1/2, p38 and p-p38 levels were observed. Evaluation of other

A
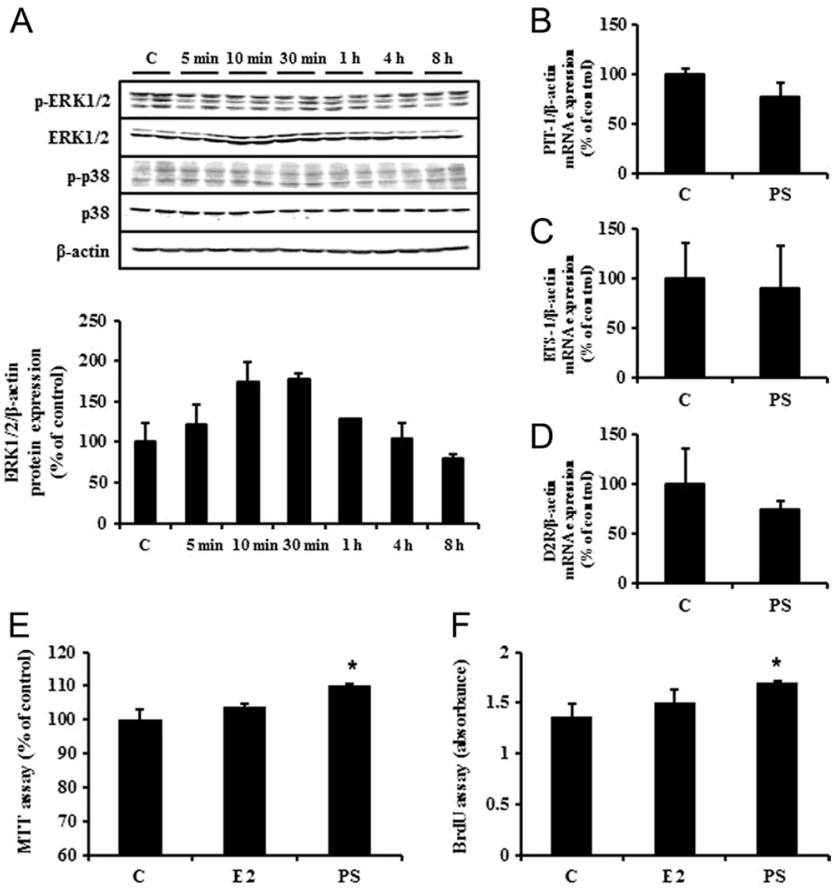

Figure 3

PS regulates PRL gene expression and cell proliferation by MAPK. (A) After treatment of GH3 cells with PS, protein levels of p-ERK1/2, ERK1/2, $p-p 38$ and $p 38$ were analyzed by Western blotting assay. The mRNA levels of PIT-1 (B), ETS-1 (C) and D2R (D) were analyzed by Q-PCR. Cell proliferation was analyzed by $\mathrm{MTT}(\mathrm{E})$ and $\mathrm{BrdU}(\mathrm{F})$ assays after treatment of $\mathrm{GH} 3$ cells with $E_{2}$ and PS. Data are expressed as mean \pm S.D. The mRNA and protein expression levels were normalized to that of an internal control, $\beta$-actin. ${ }^{*} P<0.05$ compared with the control group.

Published by Bioscientifica Ltd. 

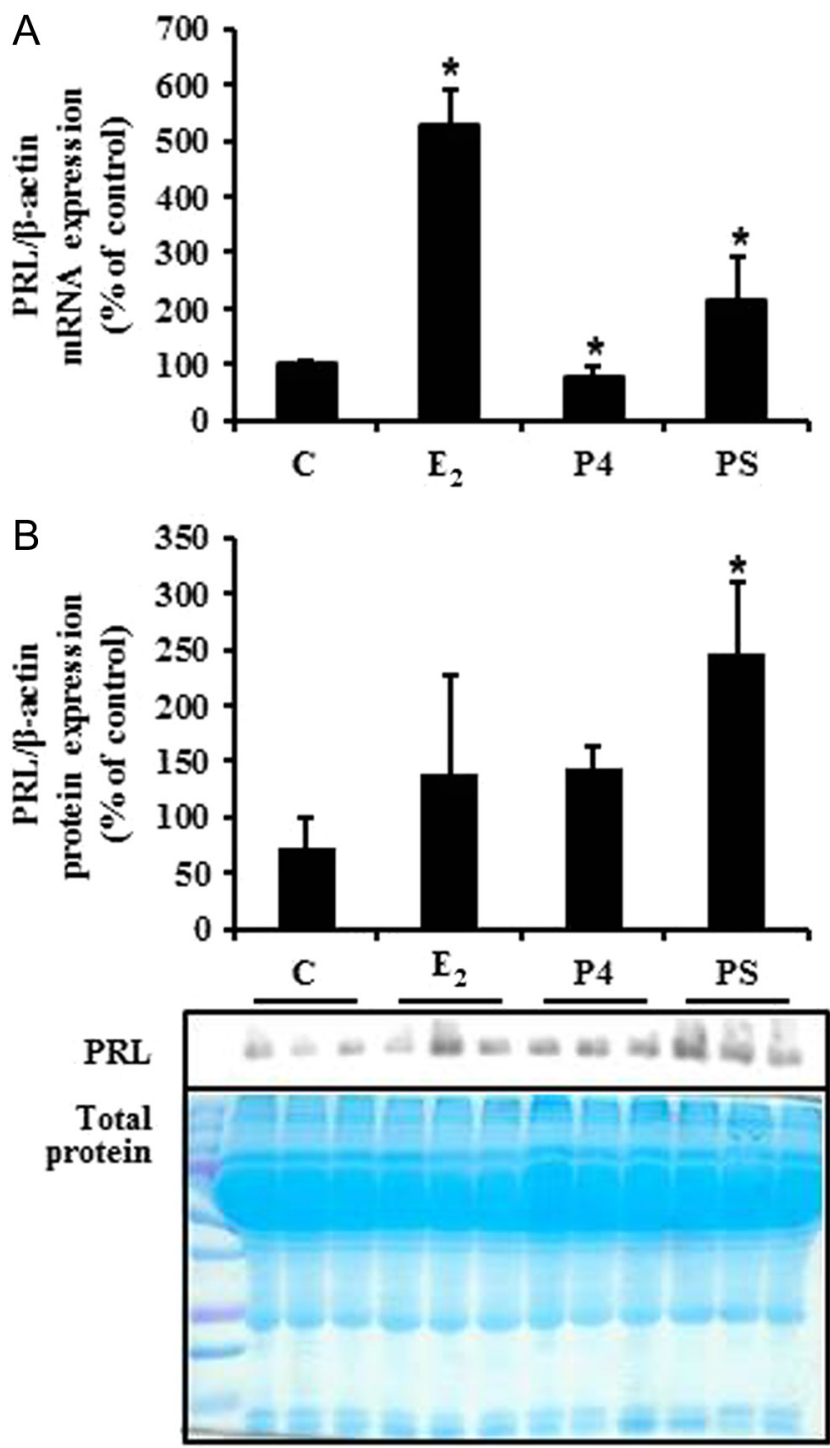

Figure 4

Regulation of PRL expression and secretion by PS in immature rats. Immature female rats were administrated $E_{2}, P 4$ and PS for 3 days, after which pituitary mRNA (A) and serum protein $(n=3)(B)$ levels of PRL were analyzed by Q-PCR and Western blotting assay. Data are expressed as mean \pm S.D. The mRNA and protein expression levels were normalized to that of total protein. ${ }^{*} P<0.05$ compared with the control group. A full colour version of this figure is available at http://dx.doi.org/JOE-16-0008.

well-known transcriptional regulators of PRL, including PIT-1, ETS-1 and D2R, was tested, which revealed that their expression levels were not significantly altered by PS (Fig. 3B, C and D).

\section{Effect of PS on GH3 cell proliferation}

To determine if PS modulates the proliferation of GH3 cells, we conducted MTT and BrdU assays. GH3 cells were treated with PS for $24 \mathrm{~h}$, after which the rate of proliferation was measured. Cell proliferation was elevated by approximately $10 \%$ in response to PS relative to the control in both MTT and BrdU results (Fig. 3E and F), suggesting that not only PRL production but also proliferation of PRL-secreting cells are augmented by PS.

\section{Regulation of PRL expression and secretion by PS in immature rats}

Following the in vitro results showing the elevation of PRL by PS in GH3 cells, we next examined the effects of PS in vivo using immature female rats. As it is known that PRL is regulated by sex steroid hormones such as $E_{2}$ and P4, we performed the experiment in sexually immature rats. The rats were treated with PS or corn oil as a vehicle control from PNDs 17 to 19, and then killed on PND 20. For comparison, P4, an endocrine metabolite of P5, was also administered. Expression of PRL in the pituitary of immature female rats was tested first because the pituitary is the main organ that produces PRL. Consistent with the results of GH3 cells, transcription of PRL increased by approximately two-fold in response to PS (Fig. 4A). To measure the amount of PRL secreted from the pituitary, PRL levels in serum were analyzed by Western blotting. PRL protein levels were upregulated by PS in serum, similar to that in the pituitary (Fig. 4B). However, $\mathrm{E}_{2}$ and P4 showed
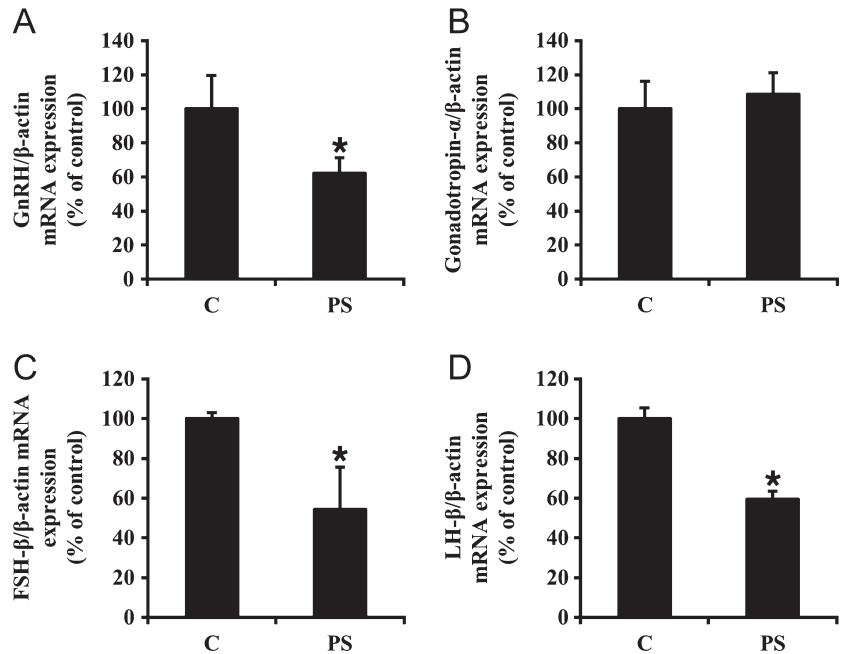

Figure 5

Regulation of PRL target genes in the pituitary of immature rats. After treatment of immature rats with PS, transcription levels of GNRH1 (A), gonadotropin- $\alpha(B)$, FSHB (C) and LHB (D) in the pituitary were analyzed by Q-PCR. Data are expressed as mean \pm s.D. The mRNA expression level was normalized to that of an internal control gene, $\beta$-actin. ${ }^{*} P<0.05$ compared with the control group.

Published by Bioscientifica Ltd. 
no significant change in serum. Then, the expression of PRL target genes such as GNRH1, gonadotropin- $\alpha$, FSHB and LHB in the pituitary was then evaluated. Among the target genes, mRNA expression of GNRH1, FSHB and LHB was reduced significantly, whereas gonadotropin- $\alpha$ expression was unchanged (Fig. 5).

\section{Discussion}

Secretion of pituitary PRL is regulated by DA, and gonadal and pituitary hormones (Fitzgerald \& Dinan 2008). $E_{2}$ regulates PRL gene expression within the anterior pituitary gland by binding to its nuclear receptor and then conferring DNA binding and transcriptional activation of the gene. The ability of physiological $\mathrm{E}_{2}$ to elicit cellular $\mathrm{Ca}^{2+}$ influx via a membrane version of ER $\alpha$ was demonstrated previously (Wozniak et al. 2005). P4 is a neurosteroid that decreases PRL synthesis and secretion, leading to inhibition of $\mathrm{E}_{2}$-induced PRL gene expression. P5, a precursor of steroid hormones, downregulates PRL via conversion to $\mathrm{P} 4$ by 3beta-hydroxysteroid dehydrogenase (3ß-HSD) (Assairi et al. 1974).

In this study, we examined the effects of PS on pituitary PRL regulation in vivo and in vitro. GH3 rat pituitaryderived cells that synthesize and secrete PRL were treated with $\mathrm{E}_{2}, \mathrm{P} 4, \mathrm{P} 5$ and PS. PS significantly increased PRL mRNA and protein levels, whereas P4 and P5 reduced PRL levels. PRL levels were elevated in growth medium by PS in a time-dependent manner compared with the negative control. These results indicate that PS upregulates both PRL synthesis and secretion. Although it has been known that $\mathrm{E}_{2}$ upregulates PRL production in GH3 cells, it did not significantly change in our experimental condition.

Because PRL secretion and synthesis increased in response to PS, we examined the mechanism of action of PS. To accomplish this, GH3 cells were pretreated with signaling inhibitors of PS action in the brain. PS is an excitatory neurosteroid in the brain that acts as a potent negative allosteric modulator of $\mathrm{GABA}_{\mathrm{A}} \mathrm{R}$ and a weak positive allosteric modulator of NMDAR (Majewska et al. 1988, Wu et al. 1991). $\mathrm{GABA}_{\mathrm{A}} \mathrm{R}$ is an ionotropic receptor and a ligand-gated ion channel that increases the membrane conductance for $\mathrm{Cl}^{-}$ions upon activation, leading to hyperpolarization and reduced excitability of neurons (Majewska et al. 1988). NMDAR is an ion channel protein that enables the flow of positively charged ions through the cell membrane when activated (Irwin et al. 1992). Transcription of PRL induced by PS was unchanged following pretreatment with $G_{A B A} R$ and
NMDAR inhibitors, indicating that PS may have different signaling pathways for the PRL regulation than its known signaling pathways. Activation of protein kinases, including PKA, PKC or MAPK, leads to phosphorylation of specific PRL regulating factors such as PIT-1 and ETS-1. Therefore, we tested PRL expression in the absence and presence of PKA, PKC and MAPK inhibitors. The results showed that PS regulated PRL gene expression via the activation of protein kinases. In addition, total ERK1/2 levels were elevated in a time-dependent manner after PS treatment, whereas the levels of phosphorylated ERK1/2 did not change. Although ERK1/2 proteins are mainly regulated by phosphorylation, evidence shows that posttranslational modifications of ERK1/2 other than phosphorylation could be involved in cellular response (Luanpitpong et al. 2012). Taken together, these findings indicate that activities of these factors may be linked via PKA, PKC and MAPK.

Although $\mathrm{E}_{2}$ and $\mathrm{P} 4$ regulated the mRNA expression of PRL in the pituitary, they did not affect PRL levels in the serum. The distinct results between mRNA and serum PRL levels may be due to the presence of other regulatory systems rather than the pituitary. Regarding the effects of PS, the results of in vivo study were similar to those of in vitro study. Transcription levels of PRL in the pituitary were elevated by approximately two-fold in response to PS. The amount of PRL was also analyzed by Western blotting assay in rat serum, which showed that PRL was upregulated by PS. However, these results demonstrate that both secretion and synthesis of PRL were increased in response to PS in immature rats. Elevated PRL may affect reproduction through its action on the GnRH neurons of the hypothalamus and/or on the pituitary gland, and secretion of the gonadotropins, $\mathrm{LH}$ and $\mathrm{FSH}$ (Grattan et al. 2007). Increased PRL expression tends to suppress expression and secretion of GnRH through PRL receptors from the hypothalamus, which reduces FSH and LH secretion from the anterior pituitary. Therefore, abnormal PRL concentration such as hyperprolactinemia and hypoprolactinemia can cause infertility in woman through interference of ovarian function (Kauppila et al. 1988). LH and FSH are heterodimers composed of $\alpha$ - and $\beta$-subunits, which are associated noncovalently (Kooy et al. 1990). In this study, the elevated PRL after PS treatment reduced the expression of GNRH1, FSHB and LHB. However, gonadotropin- $\alpha$ levels were not significantly altered. Many studies have shown that gonadotropin- $\alpha$ is differentially regulated from $\beta$-subunits, and that regulation of $\beta$-subunits is sufficient to modulate FSH and LH production (Kaiser et al. 1997).

Published by Bioscientifica Ltd. 
Taken together, these findings indicate that PS triggered activation of PKA and PKC, followed by MAPK signaling, enhanced PRL synthesis and secretion, and enhanced the proliferation of GH3 cells. The effects of PS were further evidenced in vivo based on the increased expression of PRL and the downregulation of PRL target genes. These results suggest that PS is a potential steroid hormone that can be applied to patients with PRL-related disorders such as hypoprolactinemia and milk supply.

\section{Declaration of interest}

The authors declare that there is no conflict of interest that could be perceived as prejudicing the impartiality of the research reported.

\section{Funding}

This work was supported by the National Research Foundation of Korea (NRF) grant funded by the Korea government (MOE) (No. 2014R1A1A2057387).

\section{References}

Arey BJ, Averill RL \& Freeman ME 1989 A sex-specific endogenous stimulatory rhythm regulating prolactin secretion. Endocrinology 124 119-123. (doi:10.1210/endo-124-1-119)

Assairi L, Delouis C, Gaye P, Houdebine L, Bousquet M \& Denamur R 1974 Inhibition by progesterone of the lactogenic effect of prolactin in the pseudopregnant rabbit. Biochemical Journal $144245-252$. (doi:10.1042/bj1440245)

Baulieu E 1998 Neurosteroids: a novel function of the brain. Psychoneuroendocrinology 23 963-987. (doi:10.1016/S03064530(98)00071-7)

Bole-Feysot C, Goffin V, Edery M, Binart N \& Kelly PA 1998 Prolactin (PRL) and its receptor: actions, signal transduction pathways and phenotypes observed in PRL receptor knockout mice. Endocrine Reviews 19 225-268. (doi:10.1210/er.19.3.225)

Bowlby MR 1993 Pregnenolone sulfate potentiation of N-methyl-Daspartate receptor channels in hippocampal neurons. Molecular Pharmacology 43 813-819

Cowie A 1973 Physiological actions of prolactin. Proceedings of the Royal Society of Medicine 66 861-862.

Fitzgerald P \& Dinan TG 2008 Prolactin and dopamine: what is the connection? A review article. Journal of Psychopharmacology 22 12-19. (doi:10.1177/0269216307087148)

Freeman ME, Kanyicska B, Lerant A \& Nagy G 2000 Prolactin: structure, function, and regulation of secretion. Physiological Reviews 80 1523-1631.

Gershengorn MC 1986 Mechanism of thyrotropin releasing hormone stimulation of pituitary hormone secretion. Annual Review of Physiology 48 515-526. (doi:10.1146/annurev.ph.48.030186.002503)

Gershengorn MC \& Thaw C 1985 Thyrotropin-releasing hormone (TRH) stimulates biphasic elevation of cytoplasmic free calcium in GH3 cells. Further evidence that TRH mobilizes cellular and extracellular Ca2+. Endocrinology 116 591-596. (doi:10.1210/endo-116-2-591)

Grattan DR, Jasoni CL, Liu X, Anderson GM \& Herbison AE 2007 Prolactin regulation of gonadotropin-releasing hormone neurons to suppress luteinizing hormone secretion in mice. Endocrinology 148 4344-4351. (doi:10.1210/en.2007-0403)

Irwin RP, Maragakis NJ, Rogawski MA, Purdy RH, Farb DH \& Paul SM 1992 Pregnenolone sulfate augments NMDA receptor mediated increases in intracellular $\mathrm{Ca} 2+$ in cultured rat hippocampal neurons Neuroscience Letters 141 30-34. (doi:10.1016/0304-3940(92)90327-4)

Kaiser UB, Jakubowiak A, Steinberger A \& Chin WW 1997 Differential effects of gonadotropin-releasing hormone $(\mathrm{GnRH})$ pulse frequency on gonadotropin subunit and GnRH receptor messenger ribonucleic acid levels in vitro 1. Endocrinology 138 1224-1231. (doi:10.1210/ en.138.3.1224)

Kapiloff MS, Farkash Y, Wegner M \& Rosenfeld MG 1991 Variable effects of phosphorylation of Pit-1 dictated by the DNA response elements. Science 253 786-789. (doi:10.1126/science.1652153)

Kauppila A, Martikainen H, Puistola U, Reinilä M \& Rönnberg L 1988 Hypoprolactinemia and ovarian function. Fertility and Sterility 49 437-441. (doi:10.1016/S0015-0282(16)59769-6)

Kooy A, De Greef W, Vreeburg J, Hackeng W, Ooms M, Lamberts S \& Weber R 1990 Evidence for the involvement of corticotropinreleasing factor in the inhibition of gonadotropin release induced by hyperprolactinemia. Neuroendocrinology 51 261-266. (doi:10.1159/000125348)

Lamberts S \& Macleod R 1990 Regulation of prolactin secretion at the level of the lactotroph. Physiological Reviews 70 279-318.

Le Foll F 1997 Electrophysiological effects of various neuroactive steroids on the GABA receptor in pituitary melanotrope cells. European Journal of Pharmacology 331 303-311. (doi:10.1016/S0014-2999(97)01042-X)

Lefkowitz RJ \& Labrie F 1978 Dopaminergic receptors in the anterior pituitary gland. Journal of Biological Chemistry 253 2244-2253.

Luanpitpong S, Chanvorachote P, Nimmannit U, Leonard SS, Stehlik C, Wang L \& Roianasakul Y 2012 Mitochondrial superoxide mediates doxorubicin-induced keratinocyte apoptosis through oxidative modification of ERK and Bcl-2 ubiquitination. Biochemical Pharmacology 83 1643-1654. (doi:10.1016/j.bcp.2012.03.010)

Majewska MD, Mienville J-M \& Vicini S 1988 Neurosteroid pregnenolone sulfate antagonizes electrophysiological responses to GABA in neurons. Neuroscience Letters 90 279-284. (doi:10.1016/0304-3940(88)90202-9)

Meites J, Nicoll CS \& Talwalker P 1963 The central nervous system and the secretion and release of prolactin. In Advances in Neuroendocrinology, pp 238-288. Ed AV Nalbandov. Urbana, IL, USA, University of Illinois Press.

Neill J 1970 Effect of "stress" on serum prolactin and luteinizing hormone levels during the estrous cycle of the rat 1. Endocrinology 87 1192-1197. (doi:10.1210/endo-87-6-1192)

Reddy DS 2010 Neurosteroids: endogenous role in the human brian and therapeutic potentials. Progress in Brain Research 186 113-137. (doi:10.1016/B978-0-444-53630-3.00008-7)

Sarkar DK, Hentges ST, De A \& Reddy R 1998 Hormonal control of pituitary prolactin-secreting tumors. Frontiers in Bioscience $\mathbf{3}$ d934-d943. (doi:10.2741/a334)

Terkel J, Blake CA \& Sawyer CH 1972 Serum prolactin levels in lactating rats after suckling or exposure to ether. Endocrinology 91 49-53. (doi:10.1210/endo-91-1-49)

Wozniak AL, Bulayeva NN \& Watson CS 2005 Xenoestrogens at picomolar to nanomolar concentrations trigger membrane estrogen receptor- $\alpha$-mediated $\mathrm{Ca} 2+$ fluxes and prolactin release in GH3/B6 pituitary tumor cells. Environmental Health Perspectives 113 431-439. (doi:10.1289/ehp.7505)

Wu F-S, Gibbs TT \& Farb DH 1991 Pregnenolone sulfate: a positive allosteric modulator at the N-methyl-D-aspartate receptor. Molecular Pharmacology 40 333-336.

Received in final form 15 July 2016

Accepted 18 July 2016 http://joe.endocrinology-journals.org

DOI: $10.1530 / \mathrm{JOE}-16-0088$
() 2016 Society for Endocrinology Printed in Great Britain
Published by Bioscientifica Ltd. 